\title{
Note
}

\section{Patents, Paradigm Shifts, and Progress in Biomedical Science}

\author{
Peter Lee
}

CONTENTS

INTRODUCTION.

I. THE THEORY OF PARADIGM SHIFTS 665

II. INNOVATION-ENHANCING AND INNOVATION-INHIBITING EFFECTS

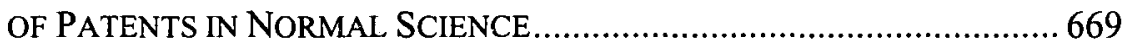

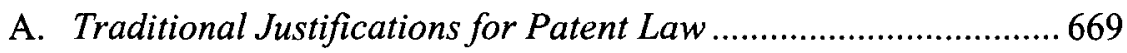

B. Rebuttals to Traditional Patent Theory:

Scientific Communism and the Tragedy of the Anticommons...... 671

1. Norms of Communal Sharing and Implications for

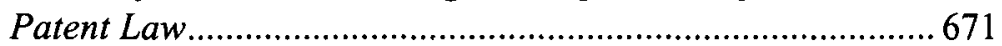

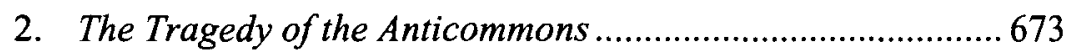

C. The Mixed Relationship of Patents to Normal Scientific Progress

III. The ChangING LANDSCAPE OF BIOMEDICAL SCIENCE AND IMPLICATIONS FOR NORMAL SCIENTIFIC PROGRESS.

A. Trends Encouraging Greater Patenting of Research Tools......... 679

B. The Narrowing of the Experimental Use Exception 681

C. Implications of Commercialization for Patent Law and Scientific Progress. 684 
IV. PATENTS, PARAdigm ShIFTS, AND SCIENTIFIC PRogreSS 686

A. Alternative Hypothesis Generation and the Path to Paradigm Shifts.... 686

B. Research Tools, Upstream Monopolies, and the Inversion of Traditional Patent Logic. 690

CONCLUSION 694 


\section{INTRODUCTION}

Conventional wisdom holds that patents contribute to progress. ${ }^{1}$ This sentiment underlies the Copyright and Patent Clause of the U.S. Constitution, which states, "The Congress shall have Power ... To promote the Progress of Science and useful Arts, by securing for limited Times to Authors and Inventors the exclusive Right to their respective Writings and Discoveries ...."2 This traditional rationale posits that grants of monopoly power provide an effective incentive for parties to invest in costly research and development to bring new inventions to market. ${ }^{3}$ Organizations such as Pharmaceutical Research and Manufacturers of America, for example, argue that patent protection is necessary to recoup the hundreds of millions of dollars in initial investments necessary to develop new drugs. ${ }^{4}$ Without such protection, copiers could simply free ride on the ingenuity and investment of creative enterprises, thus depleting the latter of any incentive to innovate. Society ultimately benefits, the conventional wisdom goes, by encouraging innovation and advancing the state of science and technology available to the public at large.

A growing counterintuitive insight, however, holds that patents actually deter innovation. At a fundamental level, patents conflict with traditional scientific norms of open sharing. Furthermore, proclaimers of the "tragedy of the anticommons" contend that overpropertization of resources results in

1. While commentators generally relate patents to scientific and technical advancement, courts have also situated patents within a broader program of social and economic progress. Regarding patent laws, the Supreme Court has noted, "The authority of Congress is exercised in the hope that '[t]he productive effort thereby fostered will have a positive effect on society through the introduction of new products and processes of manufacture into the economy, and the emanations by way of increased employment and better lives for our citizens." Diamond v. Chakrabarty, 447 U.S. 303, 307 (1980) (quoting Kewanee Oil Co. v. Bicron Corp., 416 U.S. 470, 480 (1974)) (alteration in original).

2. U.S. CONST. art. I, $\$ 8, \mathrm{cl} .8$.

3. See Bruce Abramson, Promoting Innovation in the Software Industry: A First Principles Approach to Intellectual Property Reform, 8 B.U. J. SCI. \& TECH. L. 75, 76 (2002) (arguing that the U.S. intellectual property system expressly advocates "harnessing the profit motive to promote artistic and scientific progress").

4. One oft-cited but controversial 2001 study from Tufts University estimates that the average cost to develop a new drug is $\$ 802$ million. Joseph A. DiMasi et al., The Price of Innovation: New Estimates of Drug Development Costs, 22 J. HEALTH ECON. 151, 166 (2003); see also Ceci Connolly, Price Tag for a New Drug: $\$ 802$ Million, WASH. POST, Dec. 1, 2001, at A10. Opportunity costs, however, represent almost half of this figure. Public Citizen, using data from Pharmaceutical Research and Manufacturers of America, estimates the after-tax R\&D costs for developing a new drug in the 1990 s to be $\$ 56.5$ to $\$ 71.0$ million. PUBLIC CITIZEN, RX R\&D MYTHS: THE CASE AGAINST THE DRUG INDUSTRY'S R\&D "SCARE CARD" 6 tbl.2 (2001), available at $\mathrm{http}: / / \mathrm{www}$.citizen.org/documents/acfdc.pdf. 
their underuse. ${ }^{5}$ In biotechnology, the increased patenting of "research tools"-materials, protocols, and equipment that comprise critical inputs of scientific experiments-has heightened anxieties that patents inhibit research and development. ${ }^{6}$ Revisiting the example of pharmaceuticals, patents on upstream "building block" materials or on foundational experimental protocols may hinder downstream investigations and efforts to translate basic science into useful drugs. In this manner, patents can stifle innovation and hamper progress.

While both traditional and anticommons theories focus on patents' relationship to progress in technology, ${ }^{7}$ this Note takes a different approach. Moving beyond the level of applied science, this Note examines patents' contribution to the advancement of scientific theory, the scientific community's conceptual understanding of the basic structure and properties of natural phenomena. Current scholarship has largely ignored patents' role in the evolution of scientific theory and lacks a robust analytic framework for conceptualizing this relationship. This Note looks to the "scientific humanities" to fill this void and bring to light the significant and unexpected influence of patents on scientific and inventive activity. This Note thus adds a new perspective to the intellectual property debate by drawing on the history, philosophy, and sociology of science to argue that patents may play a surprising role in the evolution of the scientific community's basic understanding of natural phenomena.

Throughout this analysis, the theory of scientific paradigms as expounded by philosopher of science Thomas Kuhn and the distinction between what he calls "normal science" and "paradigm shifts" will be central. $^{8}$ Research and application within a dominant theoretical

5. Michael A. Heller, The Tragedy of the Anticommons: Property in the Transition from Marx to Markets, 111 HARV. L. REV. 621 (1998).

6. The National Institutes of Health (NIH) defines "research tools" as "tools that scientists use in the laboratory, including cell lines, monoclonal antibodies, reagents, animal models, growth factors, combinatorial chemistry and DNA libraries, clones and cloning tools (such as PCR), methods, laboratory equipment and machines." Principles and Guidelines for Recipients of NIH Research Grants and Contracts on Obtaining and Disseminating Biomedical Research Resources: Final Notice, 64 Fed. Reg. 72,090, 72,092 n.l (Dec. 23, 1999).

7. See, e.g., Arti Kaur Rai, Regulating Scientific Research: Intellectual Property Rights and the Norms of Science, 94 NW. U. L. REV. 77, 79 (1999). While Rai evaluates the influences of law and norms on basic science research, she situates her analysis in an instrumental view that emphasizes patents' relationship to technological progress. She does not consider patents' effects on the evolution of scientific theory, instead framing her inquiry in terms of "the central instrumental goals of intellectual property-success in stimulating the creation, disclosure, and development of inventive or creative works." Id.

8. While Rebecca Eisenberg has also discussed Kuhn's framework in the context of patents' influence on basic science, see Rebecca S. Eisenberg, Patents and the Progress of Science: Exclusive Rights and Experimental Use, 56 U. CHI. L. REV. 1017, $1051-52$ (1989), this Note is unique in applying the concept of paradigm shifts to explain how patents may advance scientific theory. 
framework-what Kuhn calls a scientific paradigm-comprises "normal science." The creation of a novel theoretical framework that better explains a particular set of natural phenomena comprises a paradigm shift, the most fundamental kind of scientific change. For example, progress in normal science might involve innovatively applying current theories of neural physiology to stimulate cell growth in the human brain through the use of embryonic stem cells. In contrast, paradigmatic change would involve creating an entirely new theoretical model of how the brain works. Ultimately, a paradigm shift such as this could suggest novel ways to induce spontaneous regeneration of neurons that do not require embryonic stem cells.

Combining the concept of paradigm shifts with an anticommons approach to property theory, this Note argues that strong patent protection of research tools-critical inputs of scientific experiments-can play a vital first step in inducing paradigm shifts. This Note will review how patents conflict with scientific norms of communal sharing and how patenting upstream research tools can discourage experimentation and testing. ${ }^{10}$ By raising the cost of "doing science" within an established paradigm, however, patents encourage scientists to create alternate theories of how natural phenomena operate, theories whose investigation does not depend on using patented research tools. Patents thus accelerate the process by which researchers generate and test insurgent scientific theories. While most of these theories will prove incorrect or no better than the current paradigm in terms of empirical validity and predictive capacity, some will more successfully explain how a natural process, such as neurogenesis, functions. By accelerating the creation of alternate theories, patents increase the likelihood that scientists will challenge existing paradigms and replace them with new ones.

9. Thomas S. KunN, The STRUCTURE OF SCIENTIFIC REVOlutions 10 (3d ed. 1996).

10. One of this Note's subsidiary theses is that the lines between "basic" and "applied" research, and between "noncommercial" and "commercial" research, are increasingly blurring. Nevertheless, for purposes of clarity I will attempt to differentiate between these various kinds of scientific activity. Throughout this Note, "basic" research refers to upstream research aimed at elucidating the fundamental structure and properties of natural phenomena. While useful application of this research is conceivable, its primary goal is to uncover elementary principles. "Applied" research refers to downstream testing and experimental work that applies basic knowledge to solve practical problems. "Noncommercial" research is research motivated primarily by factors other than financial remuneration. "Commercial" research, conversely, is research primarily motivated by financial gain. While there is significant overlap between "basic" and "noncommercial" research, on the one hand, and "applied" and "commercial," on the other, these respective pairs are not coextensive. A pharmaceutical company, for example, could sponsor in-house basic science research with the clear commercial aim of developing profitable drugs. Similarly, many university-based researchers conduct applied, noncommercial research and are motivated by goodwill, curiosity, or reputational rewards. 
While this paradigm-shift-inducing dynamic may apply to a wide range of scientific disciplines, this Note will focus on biomedical research. The growing commercialization and commodification of biomedical science have allowed patents to exert substantial influence over basic research activities. Scientific, economic, statutory, and legal developments increasingly allow and encourage universities to patent products of federally funded research. In parallel, the common law doctrine of the experimental use exception-which traditionally allowed free use of patented material for noncommercial purposes-has been significantly narrowed in the context of university research. In this manner, "[b]iotechnology research presents an unusual, if not unprecedented, juxtaposition of the [proprietary] incentives of the patent law system" and the traditional scientific norm of communal sharing. ${ }^{11}$

Although scientists cannot patent abstract theories such as $E=m c^{2}$, they can patent the associated technological aids that researchers need to investigate them. ${ }^{12}$ Patents on research tools earlier and earlier in the development chain thus raise the possibility of creating individual ownership rights in theories. All theories suggest means of testing and validating themselves. The current "central dogma" of DNA translation and transcription has defined and rendered meaningful an entire material culture of technologies ranging from restriction enzymes to electrophoresis machines. These physical artifacts both reflect prevailing assumptions of DNA structure and function and allow scientists to extend, test, and apply those assumptions. Patents on biotechnology research tools can therefore effectively create exclusive rights to explore certain foundational theories. For example, patents on human embryonic stem cells restrict the universe of researchers who can investigate the hypothesis that these cells can differentiate into any type of human tissue. As research tools become more specialized and propertized, more and more fields of inquiry will ultimately fall under the domain of patents. While this raises concerns over the inhibitory effect of patents on scientific progress, it also opens the door for patents to help induce paradigm shifts.

Analyzing patent law through the lens of paradigm shifts reveals an important but underappreciated benefit of strong patent protection. Patents, by encouraging scientists to experiment outside the realm of mainstream research tools, encourage them to generate and test new theories. Some of

11. Rebecca S. Eisenberg, Proprietary Rights and the Norms of Science in Biotechnology Research, 97 YALE L.J. 177, 179 (1987) (footnote omitted).

12. Diamond v. Chakrabarty, 447 U.S. 303, 309 (1980) ("Einstein could not patent his celebrated law that $E=\mathrm{mc}^{2}$; nor could Newton have patented the law of gravity."); Funk Bros. Seed Co. v. Kalo Inoculant Co., 333 U.S. 127, 130 (1948) (stating that basic science discoveries are "manifestations of . . . nature, free to all men and reserved exclusively to none"). 
these theories will more completely and cleanly explain the operation of natural processes, thus deepening our fundamental understanding of nature. Considering the role of patents in the evolution of scientific theory thus deepens any debate on the function and value of patents. Arguments that too much patent protection deters innovation may only be considering one level of innovation - that of technological advancement. In this new light, however, any detrimental effect that patents may have on discouraging downstream research and development must be weighed against their value in encouraging the paradigm shifts that advance fundamental scientific theory. Patents emerge as a fulcrum defining the balance between two kinds of valuable scientific activity: hypothesis validation and exploration (comprising the main business of normal science) and hypothesis generation (leading to paradigm shifts). Without recognizing this function, policy choices defining patent regimes are uninformed and incomplete.

Consistent with its interdisciplinary orientation, this Note draws on several parallel sources to build its central arguments. Part I introduces the concept of paradigm shifts, the dominant framework for this Note's examination of patents and progress. Part II explores the current debate over whether patents contribute to progress, a debate that implicitly focuses on what Kuhn would call normal science. Though the Note leaves unresolved the question of whether patents, on balance, promote or hinder normal scientific progress, it does highlight the capacity for patents to create tragedies of the anticommons and stifle productive scientific exchange. Part III focuses on the increasing patenting of research tools-a result of recent scientific, economic, statutory, and legal changes-that enables patents to influence the development of new theories. Part IV applies the theory of paradigm shifts to the tragedy of the anticommons to argue that patents, by increasing the costs of research within a particular scientific paradigm, encourage scientists to "theorize around" existing paradigms, thus contributing to paradigm shifts. The Note concludes with a prescription for a time-limited experimental use exception for patented biomedical research tools to more effectively promote both the normal science and paradigm shifts that drive scientific progress.

\section{THE THEORY OF PARADIGM SHIFTS}

Thomas Kuhn's The Structure of Scientific Revolutions presents what has become the dominant contemporary theory of scientific evolution. ${ }^{13}$ Central to Kuhn's view is the concept of a paradigm: a prevailing

13. I purposefully use the term "evolution" to parallel Kuhn's characterization of scientific progress. 
theoretical framework that defines a particular branch of science at any given time. Looking historically, a paradigm exists when "some accepted examples of actual scientific practice-examples which include law, theory, application, and instrumentation together-provide models from which spring particular coherent traditions of scientific research."14 Ptolemaic astronomy, Copernican astronomy, Aristotelian dynamics, and Newtonian dynamics are all examples of scientific paradigms. ${ }^{15}$ These paradigms represent the consensus of a particular scientific community around a given theory at a particular point in time. They act as a heuristic mechanism that defines modes of promising research and provide a theoretical filter through which scientists can interpret and comprehend their findings. ${ }^{16}$

Kuhn rejected the linear, orderly, and often teleological vision of scientific progress that had long dominated historiographies of science as well as the popular imagination. ${ }^{17}$ In this traditional view, science progresses in an accumulative fashion; each discovery builds upon the vast generations of discoveries before it in an inexorable drive toward higher levels of comprehension of the natural world. Isaac Newton's famous observation, "If I have seen further it is by standing on the sho[u]lders of Giants," 18 encapsulates this vision of cumulative advancement. This accretive vision grew naturally from the orderly worldview of Newtonian mechanics and the Enlightenment commitment to progress, and reflects how most elementary science textbooks characterize scientific progress. To take an example from physics, traditionalists would see the works of

14. KUHN, supra note 9 , at 10.

15. Id.

16. While empirical validity and enhanced predictive power motivate the adoption of a new paradigm, Kuhn points out that paradigms are social constructions whose existence depends in large part on human consensus rather than objective correctness. Because paradigms represent embodiments of scientific consensus at any given time, they may be difficult to identify as they occur and their contours may exhibit some flux. A paradigm may appear more concrete to historians in hindsight than it did to individuals who practiced science within it.

17. Within the historiography of science, there is still some disagreement between those who accept an accumulative model, which emphasizes the incorporation of past achievements, and others, like Kuhn, who highlight nonlinear, revolutionary progress. See JOHN LOSEE, THEORIES OF SCIENTIFIC PROGRESS (2004) (providing arguments in favor of both accumulative and paradigmatic models of scientific advancement). Without entering the debate over which is more correct, the historical evidence in favor of Kuhn's theory corroborates its value as a framework for evaluating the relationship between patents and scientific progress. See, e.g., KUHN, supra note 9, at 11-12 (discussing the history of optics); $i d$. at 13-18 (describing the development of theories of electricity); id. at 68-69 (discussing the emergence of Copernican astronomy). Furthermore, Kuhn acknowledges the value of accumulative processes in normal science, where prior discoveries inform subsequent work within a prevailing paradigm. Id. at 15 . Therefore, the most complete reading of Kuhn reveals that his theory integrates both the accumulative model of progress in normal science and the revolutionary progress that defines paradigm shifts.

18. Letter from Isaac Newton to Robert Hooke (Feb. 5, 1675/6), in 1 THE CORRESPONDENCE OF ISAAC NEWTON, 1661-1675, at 416, 416 (H.W. Turnbull ed., 1959). 
Galileo, Newton, and Einstein as forming an orderly chain of discoveries building toward higher levels of truth.

Drawing from his empirical work both as a historian and scientist, Kuhn challenged this accretive vision. Examining myriad scientific revolutions throughout history, Kuhn concluded instead that science advances most profoundly not through smooth, linear progressions but through disjointed paradigm shifts from one dominant theoretical framework to another. The history of optics provides an illustrative example. In the eighteenth century, Newton conceived of light as material corpuscles that flew through the air. ${ }^{19}$ Later, studies by Thomas Young and Augustin Fresnel in the nineteenth century seemingly demonstrated that light was best understood as transverse wave motion. ${ }^{20}$ Finally, Planck and Einstein in the early twentieth century showed that light is composed of photons, quantum-mechanical entities that display properties of both waves and particles. $^{21}$ At each transition, empirical inconsistencies and inexplicable data ultimately forced scientists to abandon the dominant paradigm and adopt a new one that more clearly and cleanly explained observable phenomena. Our understanding of optics progressed not in a smooth linear fashion but through a succession of dramatic gestalt shifts in how scientists conceived of light.

Kuhn thus distinguished two modes of scientific endeavor: "normal science" and epoch-changing "paradigm shifts." Normal science, which characterizes the vast majority of scientific activity, involves experimentation and application within a dominant paradigm. An example of normal science is the period prior to Oswald Avery's identification of DNA as the basis for genetic inheritance, when molecular biologists around the world focused on proteins rather than nucleic acids as the material for genetic transmission. Research during periods of normal science focuses on filling out the dominant paradigm, addressing interstitial theoretical gaps, and pursuing lines of research that the paradigm itself suggests as worthwhile. The paradigm defines certain puzzles, and normal science works to solve those puzzles. ${ }^{22}$

In the course of refining the dominant paradigm, however, inconsistencies begin to emerge. In Kuhn's vision, normal science ultimately "generat[es] anomalous results that cannot be explained in terms of the prevailing theory,",23 thus leading to crisis. The paradigm becomes tattered and frayed at the edges, inviting scientists to challenge it in new

19. KUHN, supra note 9 , at 12.

20. Id.

21. Id. at $11-12$.

22. Id. at 36-39.

23. Eisenberg, supra note 8, at 1052. 
and unexpected ways. In this manner, Planck, Einstein, Heisenberg, and others abandoned Newtonian mechanics, with its emphasis on continuity, and developed quantum mechanics to explain the properties of subatomic particles. Ultimately, "insurgent" scientists discredit and discard the old theory, and a new one takes its place. A paradigm shift has occurred. Soon, normal science begins afresh, and scientists work to fill out the details and nuances of the new framework. Like Stephen Jay Gould's concept of "punctuated equilibrium," seismic paradigm shift, eventually settles into the homeostasis of normal science until a new theory comes along to displace the current one. ${ }^{25}$

Drawing from these observations, Kuhn recognized several kinds of scientific progress. Within normal science, dominant paradigms present problems, and "the result of solving those problems must inevitably be progress." ${ }^{26}$ Turning to paradigm shifts, Kuhn drew an analogy between deep scientific progress and biological evolution. ${ }^{27}$ Just as natural selection has led to a "steady emergence of more elaborate, further articulated, and vastly more specialized organisms," 28 each successive paradigm distinguishes itself from the one it displaces by representing an "increasingly detailed and refined understanding of nature." ${ }^{29}$ As with Darwinism, Kuhn felt that his vision of progress through paradigm shifts would unsettle traditionalists because it posited development away from primitive origins but toward no particular goal. ${ }^{30}$ While Kuhn denied that science had a definable teleological end, his exposition of the structure of scientific revolutions nevertheless reveals a commitment to the concept of scientific progress.

The theory of paradigm shifts thus provides an analytic framework for evaluating patent law's contribution to scientific advancement. Patent

24. STEPHEN JAy GOULD, THE STRUCTURE OF EVOLUTIONARY THEORY 745-1024 (2002) (arguing that evolution is characterized by long periods of stasis punctuated by episodes of rapid development of new biological forms).

25. Interestingly, several scholars have applied the theory of paradigm shifts to explain progress in law. In this view, a particular legal doctrine represents a dominant paradigm. In an analogy to normal science, courts hear cases and fill in interstitial gaps within the doctrine, stretching and adapting the doctrine to address novel factual predicates. Adverse outcomes or external forces such as changing social mores lead to increasing distinctions and exceptions to the doctrine. Ultimately, in a process symbolized by reversal, an authoritative court induces a paradigm shift by renouncing the old doctrine and articulating a new one to take its place. Lower courts then resume the normal business of filling out the details of the dominant legal paradigm. See Frank Michelman, Law's Republic, 97 YALE L.J. 1493, 1522-23 (1988); Laurence H. Tribe, The Curvature of Constitutional Space: What Lawyers Can Learn from Modern Physics, 103 HARV. L. REV. 1, 5 n.11 (1989).

26. KUHN, supra note 9, at 166.

27. Id. at 170-73.

28. Id. at 172.

29. Id. at 170 .

30. Id. at 172 . 
commentators have largely framed their scholarship in the utilitarian terms of the constitutional mandate " $[\mathrm{t}] \mathrm{o}$ promote the Progress of Science and useful Arts,"31 and have consequently focused on the contribution of patents to applied research and the development of useful technologies. ${ }^{32}$ Kuhn's theory, however, provides a framework for a deeper inquiry into how patents actually help advance science itself. Consequently, a novel question arises: How do patents help or hinder scientific paradigm shifts? That question represents the central concern of this Note.

In exploring the contribution of patents to paradigm shifts, it is first useful to examine how contemporary patent scholars have conceptualized the relationship between patents and progress. Arguments both for and against patents demonstrate the degree to which legal commentators have been preoccupied with relating patents to normal progress rather than to the evolution of scientific theory. Taking this analysis a step further, the argument that patents actually deter scientific exchange within prevailing paradigms is important in establishing the larger thesis that patents encourage the generation of alternate scientific theories that drive paradigm shifts.

\section{INNOVATION-ENHANCING AND INNOVATION-INHIBITING EFFECTS OF PATENTS IN NORMAL SCIENCE}

\section{A. Traditional Justifications for Patent Law}

The Copyright and Patent Clause reflects the conventional wisdom behind patent protection: Granting a limited monopoly creates incentives for innovation in science and technology. ${ }^{33}$ By constraining the free use of

31. U.S. CONST. art. I, $\S 8$, cl. 8 .

32. Intellectual property scholars have indicated that, contrary to modern connotations, "Science" relates to the copyright system while "useful Arts" relate to patents. EDWARD C. WALTERSCHEID, TO PROMOTE THE PROGRESS OF USEFUL ARTS: AMERICAN PATENT LAW AND ADMINISTRATION, 1798-1836, at 19 (1998); see In re Bergy, 596 F.2d 952, 958-59 (C.C.P.A. 1979) ("[T]he constitutionally-stated purpose of granting patent rights to inventors for their discoveries is the promotion of progress in the 'useful Arts,' rather than in science."), vacated in part sub nom. Diamond v. Chakrabarty, 444 U.S. 1028, aff'd, 447 U.S. 303 (1980); Timothy R. Holbrook, The Treaty Power and the Patent Clause: Are There Limits on the United States' Ability To Harmonize?, 22 CARDOZO ARTS \& ENT. L.J. 1, 3 (2004).

33. Malla Pollack has argued that "Progress" in the Constitution is actually best read to mean "spread" or "diffusion" rather than some notion of substantive innovation. Malla Pollack, What Is Congress Supposed To Promote?: Defining "Progress" in Article I, Section 8, Clause 8 of the United States Constitution, or Introducing the Progress Clause, 80 NEB. L. REV. 754, 755 (2001). This insight appears to run contrary to this Note's assumption that encouraging innovation represents the primary rationale for patents. Pollack, however, concedes that "according to Enlightenment Idea of Progress theorists, wide dissemination of information was a requirement for qualitative improvement of arts and sciences." Id. at 773. Ultimately, then, even Pollack's 
technical innovations, patents increase the value of such innovations and ensure that more will be generated, thus benefiting society as a whole. ${ }^{34}$ Courts have recognized that the two main objectives of the patent system are to provide incentives to invent and to disclose. ${ }^{35}$ Traditional patent theory also posits that patents provide an incentive to put existing inventions to good use. Following the creation of a new invention, considerable effort and resources are typically required to develop it into a marketable product. ${ }^{36}$ The lure of monopoly profits encourages firms to invest in developing existing inventions into practical applications. ${ }^{37}$ In a competitive economic landscape, innovative firms displace those unwilling to invest in new technologies in a dynamic process of "creative destruction." 38

Prospect theory holds that patents facilitate innovation by rationalizing the allocation of resources necessary to develop a particular invention. ${ }^{39}$ An analogy exists between patent rights and prospecting rights for mineral extraction. In the absence of such an exclusive right, a tragedy of the commons may ensue, in which multiple parties simultaneously attempt to exploit the same resources, leading to overuse and inefficient allocation of social resources. ${ }^{40}$ The sentiment that "private ownership of physical goods is justified because of the tragedy of the commons or problems with efficiency" ${ }^{41}$ applies to intellectual property as well. Whereas a single patent holder can orchestrate exploitation of a technological prospect, allowing all parties free access to that prospect may produce "chaotic, duplicative, and wasteful" effort. ${ }^{42}$

reading of "Progress" as "spread" leads to a conclusion that the Framers intended for patents to contribute to scientific progress by stimulating innovation.

34. JOAN ROBINSON, THE ACCUMULATION OF CAPITAL 87 (2d ed. 1966). Because this Note is concerned with examining the relationship between patents and scientific progress, it does not specifically corisider what can be analogized as the "authorial" rights of an inventor in his or her work. This type of claim, which finds some parallel in the copyright concept of "moral rights," might argue for patent protection based on some inherent respect for the individual integrity of the inventor. This Note instead focuses on (and extends) progress-based rationales for patent systems that have long dominated academic and policy debates.

35. Eisenberg, supra note 8 , at 1024-30.

36. Id. at 1037.

37. See JOSEPH A. SCHUMPETER, CAPITALISM, SOCIALISM, AND DEMOCRACY 81-110 (3d ed. 1950).

38. Id. at 83 .

39. See Edmund W. Kitch, The Nature and Function of the Patent System, 20 J.L. \& ECON. 265, 267-71 (1977).

40. See generally Garrett Hardin, The Tragedy of the Commons, 162 SCIENCE 1243 (1968) (discussing the concept of the tragedy of the commons and arguing that unfettered population growth threatens to deplete natural resources and is therefore unsustainable).

41. Adam D. Moore, Intellectual Property, Innovation, and Social Progress: The Case Agairst Incentive Based Arguments, 26 HAMLINE L. REV. 601, 611 (2003).

42. Richard D. Nelson \& Roberto Mazzoleni, Economic Theories About the Costs and Benefits of Patents, in NAT'L RESEARCH COUNCIL, INTELLECTUAL PROPERTY RIGHTS AND 


\section{B. Rebuttals to Traditional Patent Theory: Scientific Communism and the Tragedy of the Anticommons}

\section{Norms of Communal Sharing and Implications for Patent Law}

Contrary to traditional patent theorists, normative and transaction cost analyses reveal that patents may actually hinder progress. Sociologist of science Robert Merton has suggested that patents undermine the communal values that promote normal science. ${ }^{43}$ Merton characterized science as combining four normative pillars: universalism, communism, disinterestedness, and organized skepticism. ${ }^{44}$ While patent regimes impinge on all of these norms, they particularly impact scientific communism, the principle that " $[t]$ he substantive findings of science are a product of social collaboration and are assigned to the community." 45

Merton's empirical studies debunked the popular conception of the solitary scientist toiling alone in his laboratory. He showed instead that scientists work in communities, where sharing information, theories, and even materials fundamentally facilitates basic research. Drawing from this communal norm, Merton argued that scientific knowledge constituted "a common heritage in which the equity of the individual producer is severely limited." 46 Scientists depend on each other to validate their claims, particularly in the context of peer-reviewed scientific publications, and access to research findings and methodologies is therefore crucial. This ethic whittles individual property rights in scientific knowledge "down to a bare minimum."47

Extrapolating from these norms, Merton argued that " $[t]$ he communism of the scientific ethos is incompatible with the definition of technology as 'private property' in a capitalistic economy." 48 In his view, fencing off areas in the open plain of collaborative discovery would fundamentally

RESEARCH TOOLS IN MOLECULAR BIOLOGY 17, 23 (1997), available at http://books.nap.edu/ $\mathrm{html} /$ property.

43. As Arti Rai has pointed out, sociologists of science such as Bernard Barber and Warren Hagstrom came to similar conclusions as Merton regarding the central norms of science. Rai, supra note 7, at 89. Barber and Hagstrom were followers of Merton's school, and this Note focuses on Merton because of his foundational position in the sociology of science and the influence of his works on subsequent generations of scholars.

44. ROBERT K. MERTON, THE SOCIOLOGY OF SCIENCE: THEORETICAL AND EMPIRICAL INVESTIGATIONS 270-78 (Norman W. Storer ed., 1973).

45. Id. at 273.

46. Id.

47. Id.

48. Id. at 275. The political overtones of Merton's normative view of science were sometimes quite explicit, as when he observed that capitalism's excessive focus on individual property interests had led some scientists to advocate socialism. Id. 
frustrate science. ${ }^{49}$ Merton sharply disapproved ${ }^{50}$ of the Supreme Court's decision in United States v. American Bell Telephone Co., which stated, "The inventor is one who has discovered something of value. It is his absolute property. He may withhold the knowledge of it from the public ....".51 Ultimately, Merton perceived a sharp conflict between "the communal character of ownership in new scientific discoveries and the exclusivity of private property rights in a capitalist economy." 52

Some patent scholars have echoed Merton's condemnation of intellectual property rights, particularly in the context of biomedical research. These scholars observe a fundamental tension between the proprietary development of end-product pharmaceuticals and the research community's tradition of open, communal science. ${ }^{53}$ Privatization and commercialization "threaten to undermine certain cornerstones of our scientific infrastructure." 54 Robert Merges notes that the harsh, individualistic nature of property rights clashes with science's communal spirit. ${ }^{55}$ In tangible terms, these observations have led to "renewed interest in eliminating patents for scientific research directed toward isolating and characterizing human genes." ${ }^{956}$ The prescription arising from these critiques is a narrowing of patent regimes to preserve the communal norms that are vital to facilitating scientific exchange and, ultimately, progress itself. ${ }^{57}$

49. Id.

50. Id.

51. 167 U.S. $224,250(1897)$.

52. Eisenberg, supra note 8, at 1047.

53. See Arti K. Rai \& Rebecca S. Eisenberg, Bayh-Dole Reform and the Progress of Biomedicine, LAW \& CONTEMP. PROBS., Winter/Spring 2003, at 289, 289.

54. Robert P. Merges, Property Rights Theory and the Commons: The Case of Scientific Research, SOC. PHIL. \& POL'Y, Summer 1996, at 145, 146.

55. Id. at 145 ("[C]ommercializing the heretofore noble, pure, and otherwise untainted field of science is not just poor policy, but intrinsically bad."). Ambivalence over patent law arises not only from its conflict with norms of communal sharing in science, but also from its conflict with free-market economic principles. See, e.g., Diamond v. Chakrabarty, 447 U.S. 303, 319 (1980) (Brennan, J., dissenting) ("The patent laws attempt to reconcile this Nation's deep-seated antipathy to monopolies with the need to encourage progress.").

56. Merges, supra note 54, at 146.

57. Of course, eliminating patents would not necessarily lead to the kind of communal sharing that Merton, Merges, and others advocate. Given the increasing commercialization of science, if patents were unavailable parties could conceivably opt for different, potentially stronger forms of intellectual property claims, such as trade secrets, to protect the confidentiality of valuable information against unauthorized access. In the anticommons framework, trade secrets would have an even more deleterious impact on scientific progress, because the element of public disclosure-perhaps the only redeeming function of patent regimes in a communalist framework-would be absent. Implicit in the communalists' arguments against patents, therefore, is an assumption that even stronger forms of trade secret protection would not be available. Consistent with this conceptualization, when this Note discusses policy prescriptions to weaken patent regimes, it assumes a general loosening of intellectual property protection that would include appropriately modifying trade secret law. 
The observations of Merton and like-minded patent commentators relate to a broader debate over whether communal sharing or strictly enforced individual property rights best facilitate progress in collaborative enterprises. Yochai Benkler has described how sharing norms in areas such as parallel computing and carpooling lead to significant economic production. ${ }^{58}$ Regarding information technologies, Lawrence Lessig has argued that the Internet should function as an "information commons" based on open source technologies, ${ }^{59}$ a rationale that also underlies the Linux operating system. Such a model's commitment to sharing reflects the view that individual property rights in the information sciences may in fact discourage innovation. ${ }^{60}$ Policymakers advocating a public domain for science have also invoked the innovation-enhancing effects of the fair use doctrine in copyright. ${ }^{61}$ In a general sense, "society as a whole would be best served by the rapid and free dissemination of all newly conceived ideas, so that maximum productive use of the idea could be made at the earliest possible moment."

\section{The Tragedy of the Anticommons}

Merton's normative critique of individual property rights finds further expression among property scholars who warn against the tragedy of the anticommons. Classical property theory posits that the absence of property rights over a particular resource leads to overuse, resulting in a tragedy of the commons. ${ }^{63}$ The converse situation, in which too many individuals hold rights to exclude over the same resource, leads to inefficient underuse. Commentators have dubbed this the tragedy of the anticommons, and such a phenomenon explains why patents may actually inhibit what Kuhn would recognize as normal science, particularly in biomedical research.

An anticommons is "a property regime in which multiple owners hold effective rights of exclusion in a scarce resource." 64 Such scenarios,

58. Yochai Benkler, Sharing Nicely: On Shareable Goods and the Emergence of Sharing as a Modality of Economic Production, 114 YALE L.J. 273 (2004).

59. LAWRENCE LESSIG, CODE AND OTHER LAWS OF CYBERSPACE 6-8 (1999).

60. See Philip J. Weiser, The Internet, Innovation, and Intellectual Property Policy, 103 COLUM. L. REV. 534, 570 (2003).

61. In 1984, Congress passed the so-called Hatch-Waxman Act, which allows companies to use patented material to conduct experiments testing the efficacy and bioequivalence of generic drugs. Drug Price Competition and Patent Term Restoration (Hatch-Waxman) Act of 1984, Pub. L. No. 98-417, 1984 U.S.C.C.A.N. (98 Stat) 1585 (codified in scattered sections of 15, 21, and 35 U.S.C.). The legislative history of the Act states, "Just as we have recognized the doctrine of fair use in copyright, it is appropriate to create a similar mechanism in the patent law." H.R. REP. NO. 98-857 (pt. 2), at 30 (1984), reprinted in 1984 U.S.C.C.A.N. 2686, 2714.

62. Abramson, supra note 3, at 92.

63. See Hardin, supra note 40, at 1244-45.

64. Heller, supra note 5, at 668 (emphasis omitted). 
moreover, often result in underdevelopment of that resource. ${ }^{65}$ To explain this theory, Michael Heller compares stores with street kiosks in postcommunist Russia. ${ }^{66}$ Complex governmental regulations grant multiple parties overlapping property rights over various store functions. One individual, for example, may have the right to sell products, another the right to receive sales revenue, and yet another the right to arrange leases. ${ }^{67}$ Because disparate parties exercise effective rights to exclude over the same resource, nobody invests in developing the store, leaving shelves barren and customers scarce ${ }^{68}$ Heller contrasts this with the situation of street kiosks in Moscow: Individual owners exercise a significant amount of control over their kiosks, which attract frequent customers and whose shelves are regularly stocked with goods. ${ }^{69}$

Applied to biomedical research, the tragedy of the anticommons explains how patents may actually deter innovation. ${ }^{70}$ While earlier commentators focused on innovation as a unitary act by a single player, expositors of the tragedy of the anticommons recognize the multiparty, multiphase mechanics of contemporary research and development. Patents on upstream research tools can inhibit downstream research that depends upon those tools as critical inputs to experimentation. ${ }^{71}$ Thus, for example, patents on research tools necessary to screen therapeutic agents can inhibit a pharmaceutical company's efforts to develop marketable drugs. In short, "intellectual property rights have threatened to restrict access to materials and techniques that are critical for future research." ${ }^{.72}$ While patents have contributed to unprecedented levels of investment in biomedical research and development, in the long run their exclusionary function "may hinder rather than accelerate biomedical research.",73

A tragedy of the anticommons can impede scientific practice in several ways. In some cases, literal enforcement of the patentee's right to exclude can lead to the outright failure of scientific exchange with other researchers. Normally, however, upstream patentees have a financial incentive to

65. Id.

66. Id. at 622 .

67. Id. at 623 .

68. Id.

69. Id.

70. Michael A. Heller \& Rebecca S. Eisenberg, Can Patents Deter Innovation? The Anticommons in Biomedical Research, 280 SCIENCE 698 (1998).

71. See Rai \& Eisenberg, supra note 53, at 295.

72. Introduction, in NAT'L RESEARCH COUNCIL, supra note 42, at 1,1 ; see also David C. Mowery et al., The Growth of Patenting and Licensing by U.S. Universities: An Assessment of the Effects of the Bayh-Dole Act of 1980, 30 RES. POL'Y 99, 101 (2001) ("[W]idespread patenting and licensing of the results of fundamental research or of tools whose principal use is in further research could hinder the advance of science, and this area deserves particular attention in future research.").

73. Rai \& Eisenberg, supra note 53, at 291. 
negotiate licenses with downstream developers. In these cases, patents will not eliminate downstream appropriation but merely retard it through the friction of transaction costs. ${ }^{74}$ This raises the question of whether markets for determining licensing fees are truly efficient. Additional obstacles such as administrative burdens, time constraints, and lack of familiarity with licensing procedures may also prevent scientists from obtaining licenses for research tools even when equilibrium prices are otherwise acceptable. ${ }^{75}$ The need to independently negotiate and "bundle" licenses from multiple patent holders can significantly raise transaction costs and create potential holdout scenarios where patentees can charge a premium for their licenses. ${ }^{76}$

\section{The Mixed Relationship of Patents to Normal Scientific Progress}

Significantly, both traditional patent theorists and expositors of the tragedy of the anticommons frame their observations in the utilitarian language of promoting technological development and mainstream research. Even Merton, who addressed the role of patents in basic scientific research, situated his views in the everyday work of the scientific community and did not consider paradigmatic innovation. Both sides of the patent debate thus exhibit a preoccupation with what Kuhn would consider normal science. It is interesting to consider, moreover, the startling degree to which arguments of both schools resonate with Kuhn's framework and reveal the conflicting effects of patents on normal scientific progress.

Traditional patent theory reveals several characteristics of patents that encourage progress in normal science. The disclosure requirement helps define new paradigms by illustrating and publicizing the scientific theories that underlie novel technologies. Courts have recognized that " $[t]$ he information contained in patents is a major source of scientific as well as technologic knowledge. Indeed, in many areas of technology, technical

74. Exclusive licenses on a diagnostic test for haemochromatosis have significantly reduced the number of laboratories conducting that test. Jon F. Merz et al., Diagnostic Testing Fails the Test, 415 NATURE 577, 577 (2002). Because clinical study is necessary to further investigate the gene underlying haemochromatosis, commentators fear that "limiting clinical testing will inhibit further discovery as well as the understanding that emerges naturally from broad medical adoption." Id.

75. See WORKING GROUP ON RESEARCH TOOLS, NIH, REPORT OF THE WORKING GROUP, at "Background" (1998), available at http://www.nih.gov/news/researchtools/index.htm ("It seems to be increasingly common ... for the terms of these [material transfer] agreements to interfere with the widespread dissemination of research tools among scientists, either because owners and users are unable to reach agreement on fair terms or because negotiations are difficult and cause protracted delays.").

76. Richard A. Epstein, Steady the Course: Property Rights in Genetic Material, in PeRsPectives ON PRoperties of THE Human GenOME Project 153, 158 n.9 (F. Scott Kieff ed., 2003). 
information is not published outside of patent documents." ${ }^{\text {77 }}$ Patents further promote normal scientific progress by facilitating the most efficient use of new research tools. Disclosing the "best mode" ${ }^{, 78}$ for putting new inventions into practice provides scientists with the most effective means for utilizing patented restriction enzymes, polymerase chain reaction (PCR) protocols, and other research tools, thus accelerating exploration of particular paradigms.

Additionally, the government imprimatur of patents helps legitimate novel technologies and the theories they apply. The statutory requirements of usefulness, novelty, and nonobviousness ${ }^{79}$ all attest to the substantive merit of a new innovation. Patents validate inventions, which themselves validate theories. In this manner, Stanley Cohen and Herbert Boyer's 1980 patent on recombinant DNA cloning represented an implicit affirmation of Watson and Crick's 1959 conceptualization of the double-helix structure of DNA ${ }^{80}$ Furthermore, centralized government registration of patents helps establish scientific consensus. An intellectual property landscape featuring patents on gene splicing, PCR protocols, and oncogenic mice reveals that molecular biologists have firmly embraced the primacy of DNA both as a determinant of disease and as a promising source of new therapies. Perusing a database of patent applications can quickly reveal the lines of inquiry that a particular scientific community has deemed meaningful and worthwhile.

Finally, patents reinforce paradigms by directing research along a particular template. In licensing agreements, downstream users situate their activities, both materially and cognitively, within the original patent holder's theoretical framework. Indeed, licenses may even dictate the manner in which the patented material may be used. Licensing thus facilitates the "ffilling out" or "puzzle solving" functions of normal science. A licensing agreement is not an opportunity for challenging the basic presumptions of an underlying theory; rather, it is an event that allows extensions and refinements of a particular paradigm.

Patents, however, exhibit a split personality. While they provide incentives to invent and to disclose new products and processes, they simultaneously create a right to exclude others from using them. Patents,

77. Integra Lifesciences I, Ltd. v. Merck KGaA, 331 F.3d 860, 875 (Fed. Cir. 2003) (Newman, J., concurring in part and dissenting in part), corrected by Nos. 02-1052 \& 02-1065, 2003 U.S. App. LEXIS 27796 (Fed. Cir. June 6, 2003).

78. 35 U.S.C. $\S 112(2000)$.

79. Id. $\S \S 101-103$.

80. Though it seems odd to suggest that a foundational principle such as the double-helix structure of DNA would need affirmation, the history of science provides many examples of intense initial skepticism toward theories that appear self-evident to the contemporary mind. See, e.g., JEROME J. LANGFORD, GALILEO, SCIENCE, AND THE CHURCH (3d ed. 1992). 
therefore, have a mixed relationship to progress in normal science. ${ }^{81}$ As we have seen, patents undermine sharing norms that facilitate communal paradigm definition and exploration. While patents may help publicize new theories and research tools, patents also build proprietary fences around them that inhibit their widespread exploitation. Strictly enforced intellectual property rights, particularly on research tools, threaten collective puzzle solving within paradigms.

Furthermore, the high transaction costs associated with tragedies of the anticommons can discourage valuable knowledge transfer. Normal science is cumulative and operates best with efficient networks for scientists to appropriate and augment each other's intellectual work. Patents lead to excessive exclusivity, thus undermining scientists' capacity to gather technical knowledge and explore the theoretical contours of prevailing paradigms.

Ultimately, the degree to which patents exert a net positive or negative effect on innovation in normal biomedical science is a complex empirical question that this Note does not attempt to resolve. ${ }^{82}$ Based on interviews with intellectual property attorneys, scientists, business representatives, and government officials, John Walsh and his colleagues concluded that patents on research tools rarely prevent the pursuit of worthwhile projects. ${ }^{83}$ To a certain extent, scientific norms still generate social pressure to share materials, particularly with nonprofit entities. ${ }^{84}$ In many cases, patentholding scientists assert far less than their full exclusionary rights. ${ }^{85}$ Pharmaceutical companies frequently exercise "rational forbearance" in deciding not to sue investigators at research institutions for patent infringement. ${ }^{86}$ Some have observed a two-tiered model in which scientists freely exchange findings in the spirit of academic cooperation while

81. Furthermore, many of the normal-science-reinforcing attributes of patents can be fulfilled by other mechanisms. For example, publication in peer-reviewed journals remains the primary avenue for formal dissemination of scientific knowledge.

82. See Arti K. Rai, Proprietary Rights and Collective Action: The Case of Biotechnology Research with Low Commercial Value, in INTERNATIONAL PUBLIC GOODS AND TRANSFER OF TECHNOLOGY UNDER A GLOBALIZED INTELlECTUAL REgIME (Keith E. Maskus \& Jerome H. Reichman eds., forthcoming 2005) (manuscript at 2), available at http://ssm.com/abstract $=568521$ ("From an empirical standpoint, the net impact [on downstream development] of recent increases in upstream biotechnology rights is far from clear."); see also Iain M. Cockburn, The Changing Structure of the Pharmaceutical Industry, HEALTH AFF., Jan./Feb. 2004, at 10, 17-20 (presenting arguments both for and against strong patenting of upstream biomedical research tools).

83. John P. Walsh et al., Working Through the Patent Problem, 299 SCIENCE 1020 (2003).

84. Rai \& Eisenberg, supra note 53, at 296 ("[P] atent holders practice an informal regime of price discrimination in favor of nonprofit researchers, primarily by not enforcing their patents against such researchers for non-commercial uses.").

85. Merges, supra note 54 , at 150.

86. Leon Rosenberg, Perspectives from Different Sectors: Major Pharmaceutical Company, in NAT'L RESEARCH COUNCIL, supra note 42, at $61,63$. 
university lawyers haggle over the rights and licensing agreements. ${ }^{87}$ The NIH's declaration that raw human genomic DNA sequence information should not be patentable as a matter of doctrine and policy reflects the sustained ethos of communal sharing of scientific knowledge.

Significant evidence, however, reveals that intellectual property rights are directly or indirectly impeding productive scientific exchange in biomedical research. In one survey, Eric Campbell and others found that twenty-seven percent of geneticists cited the need to honor the requirements of an industrial sponsor as an important reason for withholding research results, techniques, and materials useful in future investigations from fellow academic scientists. ${ }^{88}$ In the same survey, twenty-one percent of geneticists cited the need to protect the commercial value of results as a reason for withholding data and materials from others. ${ }^{89}$ The 1988 decision by Cetus, a private biotechnology firm, to enforce aggressively its patent on PCR technology - even with exceptions for academic research-raised concerns that such enforcement would discourage university scientists from adopting the technology. ${ }^{90}$ Christopher Hazuka warns that the Wisconsin Alumni Research Foundation's patents on stem cells could "limit exploration of the properties and potential uses of [human embryonic stem] cells." 91 Furthermore, Michael Heller and Rebecca Eisenberg invoke the anticommons model to argue against allowing patents over gene fragments. $^{92}$ They argue, moreover, that patenting of receptors may frustrate testing that is crucial to screening candidate pharmaceuticals. ${ }^{93}$ The potentially innovation-inhibiting effects of patents have led some to argue for stricter constraints on patenting upstream experimental methods and products. ${ }^{94}$ In addition, an NIH working group has proposed remedial

87. Rebecca S. Eisenberg, Bargaining over the Transfer of Proprietary Research Tools: Is This Market Failing or Emerging?, in EXPANDING THE BOUNDARIES OF INTELLECTUAL PROPERTY: INNOVATION POLICY FOR THE KNOWLEDGE SOCIETY 223, 242 (Rochelle Cooper Dreyfuss et al. eds., 2001).

88. Eri: G. Campbell et al., Data Withholding in Academic Genetics: Evidence from a National Survey, 287 JAMA 473, 478 (2002). The most common reasons cited for withholding information and materials included the effort required to produce the requested items (eighty percent) and the need to protect a junior colleague's ability to publish findings (sixty-four percent). $I d$. These findings suggest a very different scientific reality than Merton's norm of communal sharing.

89. Id.

90. Cetus To Exact Royalties from PCR Sales; Probe Absolves Convicted Rapist, BIOTECH. NEWSWATCH, Sept. 5, 1988, at 7.

91. Christopher D. Hazuka, Supporting the Work of Lesser Geniuses: An Argument for Removing Obstructions to Human Embryonic Stem Cell Research, 57 U. MIAMI L. REV. 157, 15758 (2002).

92. Heller \& Eisenberg, supra note 70, at 699; cf. Robert Hunt \& James Bessen, The Software Patent Experiment, BUS. REV., Third Quarter 2004, at 22, 30 (noting how patent thickets in the software industry have been correlated with decreases in research and development).

93. Heller \& Eisenberg, supra note 70, at 699.

94. See, e.g., Hazuka, supra note 91 , at 220. 
measures to address the fact that "[m]any scientists and institutions involved in biomedical research are frustrated by growing difficulties and delays in negotiating the terms of access to research tools."

While further empirical investigation is necessary to quantify the net relationship of patents to normal scientific innovation, these studies indicate that patents' influence on innovation is not always salutary, and that the tragedy of the anticommons is a phenomenon to be taken seriously. If nothing else, the unique status of research tools as gateways to basic scientific research and downstream development suggests that patent law should treat them differently than traditional end products, a concept this Note more fully addresses in Part IV. As we will see, the potential to constrain normal progress appears particularly troubling given the recent expansion of patents over research tools, the inputs of basic biomedical research. Ultimately, however, these constraints may provoke attempts by researchers to transcend the limitations of normal scientific practice through innovations in scientific theory.

\section{THE CHANGING LANDSCAPE OF BIOMEDICAL SCIENCE AND IMPLICATIONS FOR NORMAL SCIENTIFIC PROGRESS}

\section{A. Trends Encouraging Greater Patenting of Research Tools}

The potential for tragedies of the anticommons is particularly salient within the field of biomedical research. Rapid scientific advances, growing commercial interest in biomedical research, changes in U.S. patent policy, and the strengthening of patent doctrine have created a contemporary landscape in which patents are increasingly influencing the mode, scope, and direction of biomedical research.

By the mid-1970s, biomedical technology had made significant strides as a productive area of university research and had attracted considerable commercial interest. ${ }^{96}$ In 1980, Stanford researchers Stanley Cohen and Herbert Boyer patented the technique for gene splicing, which became one of the most profitable university-based intellectual properity assets of its generation. ${ }^{97}$ Also in 1980 , Congress enacted the Bayh-Dole University and Small Business Patent Procedures Act, more commonly known as the

95. WORKING GROUP ON RESEARCH TOOLS, supra note 75, at "Executive Summary."

96. Mowery et al., supra note 72 , at 116 .

97. Id. at 110. The recombinant DNA patent has accounted for more licensing revenues than any other invention of the University of California or Stanford University, two early leaders in university biotechnology patenting. 
Bayh-Dole Act. ${ }^{98}$ Contrary to previous practice, the Act permitted and actively encouraged universities to patent inventions and discoveries that arose from publicly funded research. ${ }^{99}$ Though advances in molecular biology in the late 1970s had already led some universities to seek patents, patenting activity increased sharply after the passage of the Bayh-Dole Act. ${ }^{100}$

During this period, courts also strengthened patent doctrine. In 1980, the Supreme Court held in Diamond v. Chakrabarty that a live, humanmade microorganism constitutes patentable subject matter ${ }^{101}$ and thus "opened the door to patenting the organisms, molecules, and research techniques emerging from biotechnology." 102 With the express objective of unifying and strengthening the patent law, Congress created the Court of Appeals for the Federal Circuit in $1982 .{ }^{103}$ The Federal Circuit has adopted a generally supportive attitude toward patents, which has heightened patenting activity and promoted imaginative claiming strategies. ${ }^{104}$

Between 1980 and 1992, the number of patents granted annually to universities grew from 250 to almost $2700 .^{105}$ Throughout the current period of rapid scientific and technological advance, research institutions

98. Bayh-Dole University and Small Business Patent Procedures Act, Pub. L. No. 96-517, $\S 6(a), 1980$ U.S.C.C.A.N. (94 Stat.) 3015, 3018-29 (1980) (codified at 35 U.S.C. $\$ \S 200-212$ $(2000))$.

99. Notably, the Act begins by stating, "It is the policy and objective of the Congress to use the patent system to promote the utilization of inventions arising from federally supported research or development." 35 U.S.C. $\S 200$ (2000). Before the Bayh-Dole Act, university-based researchers could apply for individual patents on inventions arising from public funds, but these applications were subject to federal review on a case-by-case basis. In the 1960s and 1970s, the Department of Health, Education, and Welfare and the National Science Foundation negotiated several institutional patent agreements with individual universities. Prior to the Bayh-Dole Act, however, statutory default rules held that the federal government retained all intellectual property rights arising from publicly funded research. See Mowery et al., supra note 72, at 101-03.

100. Rai \& Eisenberg, supra note 53, at 291-92. The Bayh-Dole Act has been called "[p]ossibly the most inspired piece of legislation to be enacted in America over the past halfcentury." Innovation's Golden Goose, ECONOMIST, Dec. 14, 2002, at 3, 3. The apparent benefits of the Bayh-Dole Act have prompted attempts to emulate it in Germany and the United Kingdom. Ashley J. Stevens, The Enactment of Bayh-Dole, 29 J. TECH. TRANSFER 93, 93 (2004). Its exact contributions to patenting and scientific progress, however, are the subject of considerable academic debate. David Mowery and Arvids Ziedonis conclude that the Act itself had little effect on the content of academic research, though it did lead some universities to enter the realm of patenting and licensing. Mowery et al., supra note 72; see David C. Mowery \& Arvids A. Ziedonis, Academic Patent Quality and Quantity Before and After the Bayh-Dole Act in the United States, 31 RES. POL'Y 399 (2002) [hereinafter Mowery \& Ziedonis, Academic Patent Quality]; David C. Mowery \& Arvids A. Ziedonis, Numbers, Quality, and Entry: How Has the Bayh-Dole Act Affected U.S. University Patenting and Licensing?, 1 INNOVATION POL'Y \& ECON. 187 (2001).

101. 447 U.S. 303 (1980).

102. Mowery \& Ziedonis, Academic Patent Quality, supra note 100, at 415.

103. Rai, supra note 7, at 95.

104. Rai \& Eisenberg, supra note 53, at 290.

105. Rai, supra note 7, at 109. 
have had to adapt to declining growth in public funding for basic science research $^{106}$ and have established robust technology-transfer offices to oversee the patenting and licensing of their discoveries. ${ }^{107}$ The financial incentives at stake in university patents have further blurred the line separating noncommercial from commercial research. ${ }^{108}$ These developments have inculcated a cultural shift at universities, which now view novel materials, methods, and information developed for use in research as valuable intellectual properties. ${ }^{109}$ This ethos extends to the individual researcher as well, for "[r]egardless of what motivates a scientist,... he or she cannot make any progress in the vast majority of scientific disciplines without a great deal of money." ${ }^{10}$ This sentiment diverges sharply from Merton's vision of scientific communism and the romantic ideal of the disinterested philosopher.

Based on these developments, universities have received patents on a host of biomedical research tools, including recombinant DNA technology, ${ }_{111}$ human embryonic stem cells, ${ }^{112}$ and oncogenic nonhuman mammals. ${ }^{113}$ These materials and processes represent valuable inputs to further downstream research, "thereby accelerating the encroachment of the patent system into what was formerly the domain of open science." 114

\section{B. The Narrowing of the Experimental Use Exception}

The anticommons hypothesis depends on the exclusivity of property rights over patented material. Patent law, however, has traditionally allowed free use of patented material for strictly academic, philosophical, and noncommercial applications. In its original form, the so-called "experimental use exception" legally instantiated Merton's norm of scientific communism and facilitated the communal puzzle solving that is characteristic of normal science. The vanishing distinction between commercial and noncommercial science, however, has led to a severe narrowing of experimental use.

106. NAT'L RESEARCH COUNCIL, supra note 42, at 2.

107. Heller \& Eisenberg, supra note 70 , at 698.

108. Walter W. Powell, Networks of Learning in Biotechnology: Opportunities and Constraints Associated with Relational Contracting in a Knowledge-Intensive Field, in EXPANDING THE BOUNDARIES OF INTELLECTUAL PROPERTY, supra note 87, at 251, 251-52.

109. Eisenberg, supra note 87, at 228.

110. Merges, supra note 54, at 155.

111. Mowery et al., supra note 72 , at 110.

112. Rai \& Eisenberg, supra note 53, at 293.

113. Eisenberg, supra note 8 , at 1079.

114. Rai \& Eisenberg, supra note 53, at 291. 
Justice Story's 1813 opinion in Whittemore v. Cutter laid the foundation for the common law experimental use defense. ${ }^{115}$ Regarding an infringement suit over a card-making machine, Justice Story stated in dictum, "[I]t could never have been the intention of the legislature to punish a man, who constructed such a machine merely for philosophical experiments, or for the purpose of ascertaining the sufficiency of the machine to produce its described effects." 116 Central to this early formulation of experimental use was a distinction between commercial and noncommercial applications of patented materiai. In a later decision, Justice Story described commercial use as "the making with an intent to use for profit, and not for the mere purpose of philosophical experiment, or to ascertain the verity and exactness of the specification." 117

William Robinson's The Law of Patents for Useful Inventions, ${ }^{118}$ which courts continued to cite into the $1980 \mathrm{~s},{ }^{119}$ provided a widely influential definition of the experimental use exception. Under the title "No Act an Infringement unless it Affects the Pecuniary Interests of the Owner of the Patented Invention," the treatise asserted that where patented material "is made or used as an experiment, whether for the gratification of scientific tastes, or for curiosity, or for amusement, the interests of the patentee are not antagonized."120 Robinson's distinction between commercial and noncommercial interests resonated with court opinions such as Katz $v$. Horni Signal Manufacturing Corp., where Judge Frank observed,

Epoch-making "discoveries" of "mere" general scientific "laws," without more, cannot be patented. So the great "discoveries" of Newton or Faraday could not have been rewarded with such a grant of monopoly. Interestingly enough, apparently many scientists like Faraday care little for monetary rewards; generally the motives of such outstanding geniuses are not pecuniary. ${ }^{121}$

Judge Frank's opinion affirms Merton's scientific norm of disinterestedness; for the court, the altruistic spirit of scientific discovery was closely correlated with the universal, nonpatentable nature of scientific truth.

115. 29 F. Cas. 1120 (Story, Circuit Justice, C.C.D. Mass. 1813) (No. 17,600).

116. Id. at 1121 .

117. Sawin v. Guild, 21 F. Cas. 554, 555 (Story, Circuit Justice, C.C.D. Mass. 1813) (No. 12,391). This doctrine found further expression in later decisions, such as Poppenhusen v. Falke, which stated that "an experiment with a patented article for the sole purpose of gratifying a philosophical taste, or curiosity, or for mere amusement, is not an infringement of the rights of the patentee." 19 F. Cas. 1048, 1049 (C.C.S.D.N.Y. 1861) (No. 11,279).

118. 1-3 WiLliam C. ROBINSON, THE LAW OF PATENTS FOR USEFUL INVENTIONS (1890).

119. Eisenberg, supra note 8 , at 1034.

120. 3 ROBINSON, supra note $118, \S 898$, at 55-56.

121. 145 F.2d 961, 961 (2d Cir. 1944) (footnote omitted). 
Contemporary courts, perhaps responding to the increasingly commercial nature of scientific research, no longer view academic science in this romantic light. In 2002, the Federal Circuit held in Madey v. Duke University that Duke's use of laser technology that had been previously patented by a recently departed researcher constituted infringement. ${ }^{122}$ In holding for plaintiff Madey, the court stated that "so long as the [suspect] act is in furtherance of the alleged infringer's legitimate business and is not solely for amusement, to satisfy idle curiosity, or for strictly philosophical inquiry, the act does not qualify for the very narrow and strictly limited experimental use defense." 123 Duke had advanced the argument that it qualified for the experimental use exception because its alleged infringement served no commercial purpose and occurred within the context of nonprofit university research. The court, however, repudiated this argument with a broad interpretation of "business" application. Duke's use of the patented laser technology "unmistakably further[ed] the institution's legitimate business objectives, including educating and enlightening students and faculty participating in these projects." "24 These projects enhanced Duke's reputation and allowed it to "lure lucrative research grants, students and faculty." 225 Because Duke is in the business of teaching and conducting research, use of Madey's patented laser represented a commercial application and, therefore, patent infringement. Under Madey, universities-historically the paragons of disinterested research-can no longer unequivocally claim an experimental use defense for academic uses of patented material.

Other recent decisions have also articulated an extremely narrow construction of "experimental use." In Integra Lifesciences I, Ltd. v. Merck $K G a A$, the Federal Circuit rejected the notion of the experimental use doctrine as a complete defense to liability, noting that experimental use may be more properly regarded as "de minimis infringement better addressed by limited damages." 126 In a concurring opinion to Embrex, Inc. v. Service Engineering Corp., Judge Rader went even further, categorically asserting that "the Patent Act leaves no room for any de minimis or experimental use excuses for infringement." ${ }^{27}$ In Applera Corp. v. MJ Research Inc., the District of Connecticut reiterated Madey's "very narrow" and "strictly

122. 307 F.3d 1351 (Fed. Cir. 2002).

123. Id. at 1362.

124. Id.

125. Id.

126. Nos. 02-1052 \& 02-1065, 2003 U.S. App. LEXIS 27796, at*6 n.2 (Fed. Cir. June 6, 2003). Merck KGaA, a German pharmaceutical and chemical company, is wholly independent of Merck \& Co., the American pharmaceutical company. For convenience, this Note (as well as the Federal Circuit) refers to Merck KGaA as "Merck."

127. 216 F.3d 1343, 1352 (Fed. Cir. 2000) (Rader, J., concurring) (emphasis omitted). 
limited" view of the experimental use exception. ${ }^{128}$ The court also affirmed Madey's holding that even a nonprofit university's use of patented material could serve business objectives, thus constituting patent infringement. ${ }^{129}$ While the experimental use defense has rarely succeeded in practice, it has long been available in theory. ${ }^{130}$ Increasingly, however, courts are cutting away at the theoretical basis of the doctrine itself.

These developments have led some scholars to conclude that, in general, U.S. law does not exempt research activities from patent infringement claims. ${ }^{131}$ In response, commentators have argued that the benefits of unencumbered scientific exchange "would lead us to consider very seriously proposals to formalize a line of legal decisions hinting at a pure research exemption to patent infringement." ${ }^{\prime 32}$ The challenge of combining the powerful incentive of monopoly power with the exchangeenhancing properties of open access lies at the heart of patent policy, and is a fundamental question to which this Note will return. Nevertheless, in concrete terms, Duke and other universities are "reeling at the prospect of a 'major behavioral change"' in the wake of Madey. ${ }^{133}$ Experimental use no longer represents a practicable defense against charges of patent infringement for the vast bulk of university research.

\section{Implications of Commercialization for Patent Law and Scientific Progress}

Scientific, economic, statutory, and legal trends-including the narrowing of the experimental use exception-have set the stage for patents to exert an ever-growing influence over biomedical research. As scientists seek to patent more and more inputs of biomedical experimentation, they will patent products and processes earlier in the development chain, where patents play their most significant role.

Unsurprisingly, some have welcomed the extension of patents over research tools as bringing the traditional incentives of innovation to this

128. 311 F. Supp. 2d 293, 296 (D. Conn. 2004) (quoting Madey, 307 F.3d at 13[61-62]) (internal quotation marks omitted).

129. Id. at 297 ("The proper focus is not on whether uses are non-commercial or not-forprofit but rather whether they are in keeping with defendants' customers' legitimate business objectives, including educating project participants, and increasing the university's or laboratory's status or ability to lure research grants, students, or researchers; but not solely for amusement, to satisfy idle curiosity, or for strictly philosophical inquiry.").

130. Rebecca Eisenberg, Patenting Research Tools and the Law, in NAT'L RESEARCH COUNCIL, supra note 42 , at 6,11 .

131. Eisenberg, supra note 87 , at 223 n.1.

132. Merges, supra note 54 , at 164 .

133. Mark D. Uehling, BIO-IP 'Harbor' No Longer Safe For Research?, BIO-IT WORLD, Aug. 13, 2003, at 1, available at http://www.bio-itworld.com/news/081303_report3076.html (quoting David Korn, Am. Ass'n of Med. Colls.). 
specialized class of products. In Integra Lifesciences I, the Federal Circuit considered Integra's claim that Merck had infringed various patents dealing with a peptide sequence that promotes cell adhesion. ${ }^{34}$ In its defense, Merck invoked 35 U.S.C. $\S 271(\mathrm{e})(1)$ (originally passed as part of the Hatch-Waxman Act), which allows companies free use of patented materials for the purpose of conducting preliminary tests on candidate drugs for FDA approval. ${ }^{135}$ The Federal Circuit rejected Merck's unlicensed use of the peptide, a research tool, explaining that allowing Merck's free use of this material "would effectively vitiate the exclusive rights of patentees owning biotechnology tool patents." ${ }^{136}$ Recognizing the value of research tools in various aspects of drug development, ${ }^{137}$ the court stated that the incentives and rewards of the patent system should be available to encourage the creation and marketing of these products.

The concerns of the anticommons school thus appear to have considerable weight. Arti Rai contends that "the highly aggressive patenting of basic research encouraged by post-1980 statutory and case law does not in fact further the economic goal of developing new products." Consequently, she argues for a larger public domain in research. ${ }^{139}$ Even scientists who have no intention of patenting their discoveries run up against the patents of others when attempting to use protected research tools. ${ }^{140}$ Significantly, patent doctrine accentuates the ramifications of patents on research tools. "Because the princip[al] constraint on the scope of patent claims is prior knowledge in the field of the invention," patents on research tools in novel fields lacking prior art may be quite broad. ${ }^{141}$ In this manner, patents on products, processes, and equipment in relatively unexplored fields can grant scientists an extensive scope of proprietary rights over uncharted territory.

On a deeper level, the increasing patenting of research tools means that the "private fence" of property rights will come nearer and nearer to enclosing theories themselves. Traditional patent doctrine confines patent

134. Nos. 02-1052 \& 02-1065, 2003 U.S. App. LEXIS 27796 (Fed. Cir. June 6, 2003).

135. 35 U.S.C. $\S 271(\mathrm{e})(1)(2000)$. This provision of the Hatch-Waxman Act is commonly referred to as an "experimental use exception," but it is a very different kind of exception than Justice Story's creation in Whittemore. The Hatch-Waxman exception allows pharmaceutical firms to use protected material in order to conduct tests to develop potential generic versions of patented drugs. Id.; see supra note 61. As such, it contemplates a clear commercial application of patented material, which distinguishes it from the Whittemore doctrine that specifically and solely exempted noncommercial uses of patented material in scientific inquiry.

136. Integra Lifesciences I, 2003 U.S. App. LEXIS 27796, at *18.

137. Id. at *18-19 ("After all, patented tools often facilitate general research to identify candidate drugs, as well as downstream safety-related experiments on those new drugs.").

138. Rai, supra note 7, at 115.

139. Id. at 152.

140. Eisenberg, supra note 11 , at 197.

141. Rai \& Eisenberg, supra note 53, at 296. 
protection to applied technologies rather than their underlying theories. Courts have denied patent protection for theoretical or abstract discoveries, ${ }^{142}$ natural laws, ${ }^{143}$ naturally occurring products, ${ }^{144}$ and mathematical algorithms. ${ }^{145}$ But all theories give rise to a unique material culture that enables researchers to demonstrate, investigate, and validate them. ${ }^{146}$ Newton's hypothesis that white light contains the full spectrum of colors is intimately related to the physical prisms he used to split light. Abstract theories of high-energy physics and subatomic particles find physical expression in the concrete, wires, and intricate designs of particle accelerators. The current biological paradigm focusing on the therapeutic potential of DNA manipulation has produced and assigned great value to a closely related material culture of gene splicing techniques, PCR protocols, and human embryonic stem cells. If the materials and procedures necessary to investigate a particular theory are strictly patented, then in some relevant sense individual property rights inhere in the theory itself. These exclusive rights to explore theories, moreover, can play an important role in inducing paradigm shifts.

\section{Patents, Paradigm Shifts, AND SCIENTIFIC Progress}

\section{A. Alternative Hypothesis Generation and the Path to Paradigm Shifts}

While traditional patent scholarship argues that patents promote progress, the anticommons theory counterintuitively posits that patents may have the opposite effect. This Note offers another perspective and applies the theory of paradigm shifts to reveal once again how patents contribute to progress, though in terms and scope that neither traditional patent scholars nor proponents of the anticommons have addressed. Patents on upstream research tools raise the cost of conducting downstream biomedical research. At the margin, these higher costs provide an extra incentive for scientists to reconceptualize "familiar" natural processes in ways that do not rely on patented research tools for their exploration. Patents on critical inputs to experimentation thus encourage the generation of radically novel theories

142. Mackay Radio \& Tel. Co. v. RCA, 306 U.S. 86, 94 (1939); In re King, 801 F.2d 1324, 1328 (Fed. Cir. 1986).

143. Diamond v. Chakrabarty, 447 U.S. 303, 309 (1980).

144. Funk Bros. Seed Co. v. Kalo Inoculant Co., 333 U.S. 127 (1948).

145. In re Abele, 684 F.2d 902 (C.C.P.A. 1982).

146. See, e.g., Robert E. KoHler, LoRdS OF THE Fly: Drosophila Genetics AND the EXPERIMENTAL LIFE (1994) (exploring how the common fruit fly, Drosophila melanogaster, has been a remarkably productive research tool whose properties have suggested many lines of genetic research). 
about the structure and function of natural phenomena, an essential first step in paradigm shifts.

In Kuhn's framework, empirical inconsistencies and limitations of predictive power motivate scientists to challenge a dominant paradigm with insurgent theories. Patents provide additional incentives-legal and economic-to theorize outside of a dominant paradigm. If specific biological materials are indispensable for conducting a certain line of research, patents on those materials can hinder experimentation to such an extent that a scientist is induced to develop alternate ways of conceptualizing and investigating the subject of her research. After all, "[w]hen progress in research depends on the relatively unfettered flow of low value exchanges of information and materials among scientists, a proliferation of intellectual property claims to the objects of these exchanges may impose transaction costs that consume the gains from exchange." $" 147$ In traditional patent theory, patents provide an incentive to innovate in order to receive payments from others; in an anticommons or Kuhnian sense, patents provide an incentive to innovate in order to avoid paying someone else and accepting exogenous constraints on one's research. These legal and economic considerations shore up existing empirical, epistemological, and reputational incentives for challenging dominant paradigms. Consistent with Kuhn's framework, patents can induce failures of normal science that then provoke paradigm shifts.

Central to this argument are the unique role of research tools as gateways to basic research, the growing commodification of science, the rise of patents on research tools, and the consequent encroachment of patents on the realm of abstract theory. Patents are increasingly important to determining whether and how a scientist engages in a particular line of experimentation. Commercial pressures are motivating increased patenting of research tools, which include inputs earlier and earlier in the development chain. The costs and limitations of working with patented research tools provide an incentive for scientists to seek out new ones. This can translate into an incentive to fundamentally reconceive of particular scientific problems in ways that do not depend on patented inputs for their exploration. For a neuroscientist working on a treatment for Alzheimer's disease, the exclusive patents on human embryonic stem cells provide an incentive not only to investigate alternate mechanisms for neurogenesis but also to test alternate theories of brain structure, physiology, and the pathology of Alzheimer's itself.

A landscape of heavily patented research tools will, of course, engender different responses from different scientists. Some may expend the

147. Eisenberg, supra note 87, at 234. 
resources to collect multiple licenses, others may abandon a particular line of research, and others may simply infringe and risk litigation. At the margin, however, the obstacle of patents will provide the additional incentive for some scientists to imagine, formulate, and test novel theories of natural phenomena that require an entirely unprecedented set of research tools for their investigation. By preventing scientists from exploring mainstream theories, patents encourage them to develop novel ones. ${ }^{148}$

Interestingly, courts have long recognized an analogous property of patents, though they have never applied it in Kuhnian terms at the level of scientific theory. In State Industries v. A.O. Smith Corp., for example, the Federal Circuit concluded, "One of the benefits of a patent system is its socalled 'negative incentive' to 'design around' a competitor's products, even when they are patented, thus bringing a steady flow of innovations to the marketplace." 149 The Federal Circuit, in another case citing State Industries, likewise held that the "incentive to 'design around' patents is a positive result of the patent system." 150 Courts, then, have recognized the valuable burdensome role that patents play as roadblocks that innovators must then creatively evade. While judicial discussions of "inventing around" have only addressed the level of technological designs, the concept of paradigm shifts illustrates that "inventing around" also operates at the level of scientific theory. By analogy, patents on research tools-vital inputs to basic science experimentation-encourage scientists to "theorize around" established paradigms.

This radical theorization represents the alternative hypothesis generation lying at the heart of paradigm shifts. This Note does not argue that the obstacle of patents will automatically lead an insurgent theorist to put forth a more "correct" alternative theory. The mechanism by which patents encourage paradigm shifts involves much wasted activity, ${ }^{151}$ which is perhaps an intrinsic quality of macroscopic scientific (as well as organismic) evolution. In some cases, it may simply be impossible to find a route to scientific progress that does not require using research tools belonging to another party. In other cases, however, the roadblock of patents will stimulate scientists to generate new hypotheses about how a particular biological process functions. Many of these hypotheses will

148. It would be ideal to be able to cite case studies where research tool patents so frustrated scientists that they developed newer and more accurate theories about a particular scientific problem. The extension of patents over research tools in biomedical science, however, is a relatively recent phenomenon, coinciding with scientific, economic, statutory, and legal developments of the past few decades. In a wider sense, paradigm shifts of any magnitude are extremely rare. Therefore, while patents sow the seeds for paradigm shifts, the dynamic described here may require several generations to fully come to light.

149. 751 F.2d 1226, 1236 (Fed. Cir. 1985).

150. Yarway Corp. v. Eur-Control USA, 775 F.2d 268, 277 (Fed. Cir. 1985).

151. See Eisenberg, supra note 8, at 1027-28. 
prove wrong, and their failures will further validate the existing paradigm. But just as one random mutation among billions will lead to a fitnessenhancing adaptation, some alternative theories will more cleanly and completely explain how natural processes function and will exhibit greater predictive capacity than the current state of the art. This type of alternative hypothesis generation is the critical imaginative spark that induces paradigm shifts.

Kuhn's observations highlight the deep, paradigmatic progress that defines scientific revolutions. Applying these observations to the empirical realities of modern commercial research, the traditional links between patents and progress appear to be inverted. As Bruce Abramson explains,

The patent system was designed to insure that the knowledge embodied in the patented good is disseminated widely, while the commercial exploitation of that knowledge by anyone other than the patent holder is severely restricted. This protection may be viewed as shallow for scientific purposes but deep for commercial purposes. $^{152}$

Within the anticommons reality of modern biomedical research, patents can frustrate downstream development and create an incentive to fundamentally reconceptualize research problems. Paradoxically, intellectual property protection in the biomedical field may actually function as shallow for technological progress but deep for scientific purposes. Christopher Hazuka asks the rhetorical question, "[I]s the patent system promoting innovation overall when thousands of laboratories, physicians, and scientists must... pay for the right to study or use [a particular] DNA sequence to develop therapies?" 153 Considering only the conditions most conducive to alternative theory generation, the answer may be a surprising yes. ${ }^{154}$

152. Abramson, supra note 3, at 99 (footnote omitted). Though Abramson does not frame his observations in these terms, one could analogize "scientific purposes" to the deep progress of paradigm shifts and "commercial purposes" to the application of prevailing theory, a characteristic of normal science.

153. Hazuka, supra note 91 , at 172-73.

154. In highlighting the benefits of paradigm shifts, it is important to acknowledge their extreme rarity relative to normal scientific activity. Paradigm shifts are once-in-a-generation (indeed, generation-defining) events, whereas normal science comprises the vast majority of scientific activity at any given time. For some, the prospect of structuring the patent system to favor seismic paradigm shifts at the expense of normal science may be likened to striving for wealth by spending all of one's income on lottery tickets. Several responses to this counterargument arise. First, if expected income is a product of the magnitude of a particular payoff and its probability of occurring, then the profound-perhaps immeasurable-value of paradigm shifts may indeed justify a "wasteful" patent system that encourages their inducement. One must bear in mind that evolutions of scientific theory are valuable not only as epistemological ends in themselves, but as gateways to new generations of useful applications that exploit more sophisticated understandings of nature. Regarding the issue of probability, policymakers can attempt to calibrate patent regimes to accelerate hypothesis generation and increase the frequency 
While this Note has framed paradigm shifts as distinct from normal science, it is important to underscore the centrality of normal science to facilitating these profound reformulations of scientific theory. Normal science and paradigm shifts form an inseparable dialectic in which one defines and induces the other. Patents on research tools encourage scientists to take the foundational step of positing new theories and conducting experiments to evaluate them. In order to truly challenge the dominant paradigm, however, a new theory must be subject to normal scientific processes of falsification ${ }^{155}$ and validation; only consistent affirmation of an insurgent theory provides the necessary predicate for a paradigm shift.

Therefore, any attempt to encourage paradigm shifts must in some ways encourage normal science as well. This Note has highlighted the possibility that restricted access to research tools-and the concomitant inability to explore certain theories-will encourage scientists to "trade upward" for more sophisticated, empirically accurate paradigms. The possibility exists, however, for scientists to "trade downward," creating and even defending theories of biological phenomena with even less scientific merit than the status quo. The crucial mechanism that separates the meritorious wheat from the merely speculative chaff is normal science. Consequently, this Note's account of the benefits of an overpropertied research tool landscape should not be interpreted as a wholesale endorsement of restrictions on basic experimental inputs. After all, if normal science grinds to a halt, paradigm shifts will as well. Consequently, an ideal patent system would preserve both the normal-science-facilitating function of open access and the paradigm-shift-encouraging function of exclusive property. While the current patent system attempts to strike the proper balance, the prospect of monopolies on upstream, gateway research tools counsels for a surprising inversion of traditional patent logic.

\section{B. Research Tools, Upstream Monopolies, and the Inversion of Traditional Patent Logic}

In this analysis, patents emerge as a switch that can selectively create conditions conducive to paradigm shifts or conditions conducive to normal science. Strict enforcement of patent rights over research tools, coupled with the collective action problems inherent in the anticommons and the

of breakthrough discoveries. Second, insistence on a stark dichotomy between normal science and paradigm shifts is a category mistake that misses the deep interrelationships between the two. As we will see, any meaningful attempt to structure a patent system to induce paradigm shifts must also ensure the robust operation of normal science.

155. See KARL POPPER, THE LOGIC OF SCIENTIFIC DISCOVERY (1959) (arguing that one of the defining attributes of science is that its claims are subject to "falsification," whereby a single substantiated counterexample can undermine a theory's validity). 
absence of an experimental use exception, encourage the alternative hypothesis generation that sparks paradigm shifts. Intrinsic to the design of a patent system, however, is not just the period during which exclusive rights obtain. Equally important is the long-term equilibrium in which the law enables free appropriation of the innovative work of others. Expiration of the patent term initiates a legally sanctioned, essentially infinite period when intellectual assets that had required considerable private investment to produce are relegated to the public domain, thereby facilitating normal science. Given this more nuanced understanding of progress dynamics, policymakers may consider new models for structuring and sequencing these functions to better capture the benefits of both public access and private incentives to innovate.

While discussions of paradigm shifts and normal science necessarily engender a high degree of abstraction, Kuhn's framework reveals tangible policy prescriptions for structuring patent regimes. This analysis suggests a new model for patents on research tools in which a robust experimental use exception would exist for a finite period of time immediately following the granting of a patent. Under this proposal, materials and processes meeting the NIH definition of a research tool ${ }^{156}$ would only be eligible for a new kind of patent, a so-called "research tool patent." A research tool patent would be identical to a traditional patent except for one critical difference: A robust experimental use exception would exist for a period of time-say five years-at the start of the patent term. ${ }^{157}$ During this period, noncommercial experimental use of the patented research tool would be permitted, as in the experimental use doctrine prior to Madey. ${ }^{158}$ Upon expiration of this safe harbor, any nonlicensed use of the patented material, even for experimentation with no direct commercial application, would

156. See supra note 6. Under this proposed model, the Patent and Trademark Office (PTO), perhaps in consultation with the NIH, would determine whether or not a particular candidate product or process that satisfies all the requirements for patentability would receive a research tool patent or a traditional patent. PTO officials could consider the patent applicant's own assessment of whether the item constitutes a research tool, but the PTO would retain the discretion to make the final determination.

157. Defining an optimal length for the experimental use period would require Congress to investigate the cost structure of creating new research tools, rates of research tool invention and obsolescence, and the time horizon for conducting biomedical experiments. I suggest five years here as a reasonable balance between permitting sufficient time for scientists to conduct and publish experiments with novel research tools and allowing creative firms to begin recouping their costs relatively soon after their initial costs investments.

158. This proposal would use a more expansive definition of "experimental use" than the Federal Circuit articulated in Madey that would exempt ali uses of a research tool that were not intended to produce, or that did not actually produce, a commercial application. This definition of "experimental" would thus reject the Federal Circuit's overly formalistic reasoning that Duke's use of patented laser technology constituted a business application simply because conducting research is the mission of a research university, see Madey v. Duke Univ., 307 F.3d 1351, 136162 (Fed. Cir, 2002). 
constitute infringement, as per the Federal Circuit's holding in Madey. ${ }^{159}$ In this model, liberal experimental use of novel research tools would allow for the communal sharing that facilitates normal science within a given paradigm. ${ }^{160}$ Free access to research tools closely associated with an insurgent theory of natural causation would enable members of the scientific community to engage in the crucial process of testing, refuting, and perhaps validating that theory. After a fixed period of open access, strict patent protection (even on experimental use) would commence, establishing the exclusive rights and high transaction costs that encourage innovation and paradigm-shifting theory generation.

Ironically, this system would invert current legal frameworks of intellectual property. Traditionally, patent terms commence by granting monopoly rights over new inventions, and expiration of the term initiates an open-ended period of free appropriation. Likewise, copyright law gives authors exclusive rights to control their works for a fixed period of time, after which they fall into the public domain. ${ }^{161}$ The system described here would privilege open access to novel research tools first, after which exclusive rights would revert to the original patentee in order to maintain the requisite incentives to innovate.

The key distinguishing factor that justifies this special treatment is the unique role that research tools play in enabling basic science research and downstream experimentation. Immediate access to research tools serves two valuable goals that do not apply to traditional end products. First, if research tools such as human embryonic stem cells are gateways to exploring a new scientific paradigm, free or low-cost access to those research tools is necessary to quickly and effectively explore the contours and scope of that paradigm. Access to research tools facilitates "filling in" interstitial gaps and identifying areas of promising subsequent investigation and technical exploitation. Second, immediate access to research tools is necessary to subject novel theories to falsification. ${ }^{162}$ Patents on research tools, while encouraging alternate theory generation, threaten to stagnate

159. Id. at 1362 .

160. Of course, this arrangement raises the potential for parties to appropriate materials protected by research tool patents under the guise of "experimental use," only to apply them to develop commercially valuable products that they then wish to patent. Under this proposal, the original research tool patentee would maintain ordinary patent rights to any commercial application of her patented material; all parties desiring to develop commercial applications from patented research tools within the first five years would be free to negotiate licenses to do so. During the five-year period, the granting of licenses for particular commercial applications would not affect the rights of third parties to continue unlicensed experimental use of patented research tools.

161. The duration of copyright varies depending on a number of factors, including when the author fixed or published the work. See 17 U.S.C. $\S \S 301-305$ (2000).

162. POPPER, supra note 155. 
normal science, allowing neither exploration nor refutation of broad conceptual assertions. Therefore, this Note proposes a time-limited experimental use exception to allow researchers unfettered access to novel research tools for the purpose of conducting normal science.

These observations call into question the prudence of treating all classes of products-whether upstream enablers of downstream development or end-product consumer goods-identically in the eyes of the patent law. Creating monopolies of building-block resources in an upstream-downstream relationship presents qualitatively different problems than creating side-by-side monopolies of end products. ${ }^{163}$ Research tools are, by definition, critical inputs of scientific experimentation and are often necessary to elucidate basic scientific theories. Therefore, as the anticommons proponents might argue, patents on research tools may uniquely frustrate the constitutional prerogative to "promote the Progress of Science and useful Arts." "164

Ultimately, however, as this Note has sought to establish, the exclusionary function of patents can play an important role in the alternate hypothesis generation that lies at the heart of paradigm shifts and innovation in scientific theory. To the extent that research tools create proprietary fences around particular theories of physiology, pathology, or molecular biology, incentives to create new research tools also encourage scientists to create new theories for the natural phenomena they investigate. Though ignoring the vast potential for paradigm shifts, the Federal Circuit is correct in acknowledging the immense value of research tools and the worthiness of a system that helps produce them. ${ }^{165}$ This Note thus proposes a patent system that employs exclusive monopolies to encourage innovation in research tools, though only after an initial period of free experimental use. This proposal differs critically from that of Robert Merges, who calls for formalizing a pure research exemption in patent doctrine. ${ }^{166}$ Merges's proposal rightly recognizes the value of open access to research tools in advancing what Kuhn would recognize as normal science. Merges underappreciates, however, the role of exclusive property rights in spurring, in some ways mandating, innovation. While permanent open access to research tools may encourage innovation and development within a paradigm, such a system may fail to capture the immense value of innovations in paradigms themselves.

163. Epstein, supra note 76 , at $163,166$.

164. U.S. CONST. art. I, $\S 8$, cl. 8.

165. Integra Lifesciences I, Ltd. v. Merck KGaA, Nos. 02-1052 \& 02-1065, 2003 U.S. App. LEXIS 27796, at*18-19 (Fed. Cir. June 6, 2003).

166. Merges, supra note 54, at 164. 
Imposing rights to exclude on research tools will ensure that insurgent scientists face a legal landscape amenable to questioning those tools' implicit theoretical assumptions. By combining an initial experimental use exception with a generally strict patent regime on research tools, the patent system can better enable both the normal science that evaluates theories and the alternative hypothesis generation that produces new ones. In this manner, patents can help accelerate the disparate processes that drive paradigm shifts and the evolution of scientific theory.

\section{CONCLUSION}

This Note has applied insights from the history, philosophy, and sociology of science to describe how exclusive property rights in critical inputs to basic research may help induce paradigm shifts in biomedical science. Traditional patent theorists focus on the positive effects that patents exert on scientific and technological innovation. Critics, however, argue that patents on upstream research tools disrupt norms of communal sharing and can impede downstream experimentation and application. Scholars on both sides of the debate have implicitly framed their arguments in the utilitarian language of technological innovation. This Note has applied Thomas Kuhn's concept of paradigm shifts to explore the impact of patents on a different, more profound kind of progress: innovation at the level of basic scientific theory.

For Kuhn, the deep progress inherent in scientific revolutions arises through paradigm shifts in which insurgent theories challenge and ultimately overturn the dominant conceptual frameworks of the day. Kuhn's framework is particularly salient to contemporary patent doctrine and biomedical science given the encroachment of research tool patents into the realm of scientific theory. The increasingly commercial nature of even university-based research has created a close nexus between patents and basic science, with parties patenting elemental research tools that are crucial to exploring wide areas of theoretical interest. This Note does not resolve the empirical question of whether patents, on balance, facilitate or frustrate normal scientific progress; ultimately, such resolution is unnecessary for this Note's central agenda, which is to describe the surprising contribution of restricted access to biomedical research tools to paradigm shifts.

Patents, by raising the cost of using research tools fundamental to a given paradigm, provide scientists with an additional incentive to innovate at the level of scientific theory. This is not the "shallow" innovation of filling in the details of an existing paradigm. It is the more profound innovation comprising a gestalt switch in how a researcher conceptualizes a 
particular scientific problem. Patents thus encourage nonconformist theorizing around dominant conceptual frameworks and can ultimately induce paradigm shifts. Normal science, however, plays a critical role in this process as the mechanism by which scientists evaluate, validate, and refute novel theories. Consequently, this analysis suggests an inversion of traditional patent logic so that a time-limited experimental use exception prevails in the period immediately following the granting of a patent on a research tool. This limited experimental use exception would enable immediate, costless appropriation of new research tools as well as maintain the long-term incentives to innovate inherent in strong patent regimes.

Underlying these analyses is an assertion that the history, philosophy, and sociology of science can elucidate previously unrecognized effects of patents on scientific activity. Current patent scholarship has not fully engaged the relationship between patents and the evolution of scientific theory, and the scientific humanities can provide a robust theoretical framework for filling this void. Without recognizing that patents can influence paradigm shifts, policy choices defining intellectual property regimes are uninformed and incomplete. While this Note has focused on research tools in biomedical science, these phenomena may operate in other fields of patented material as well. More empirical study is necessary to delineate and quantify the precise ways that patents encourage and frustrate normal collaborative development. At a minimum, the progress dynamics developed in this Note highlight the unique differences between upstream and downstream monopolies, and recommend a reexamination of the current patent system's identical treatment of gateway and end-product materials and processes. Contrary to romantic conceptions, science is not an insular enterprise detached from the wider influences of society. Increasingly, the basic science sector must contend with the powerful exogenous forces of patents and commercial pressures. It is therefore incumbent on policymakers, courts, and legal scholars to develop a greater sensitivity to the intricate and unexpected ways that law impacts scientific progress and to structure patent regimes accordingly. 
